\title{
Sickle Cell-Hemoglobin D Disease
}

National Cancer Institute

\section{Source}

National Cancer Institute. Sickle Cell-Hemoglobin D Disease. NCI Thesaurus. Code C155310.

A variant of sickle cell disease due to heterozyg osity for hemoglobin $S$ and hemoglobin $D$ mutations. Patients present with the symptoms of sickle cell disease but the symptoms are less frequent and severe compared to patients with hemoglobin SS disease. 